"IFRS and stock exchange development in sub-Saharan Africa: a logistic model"

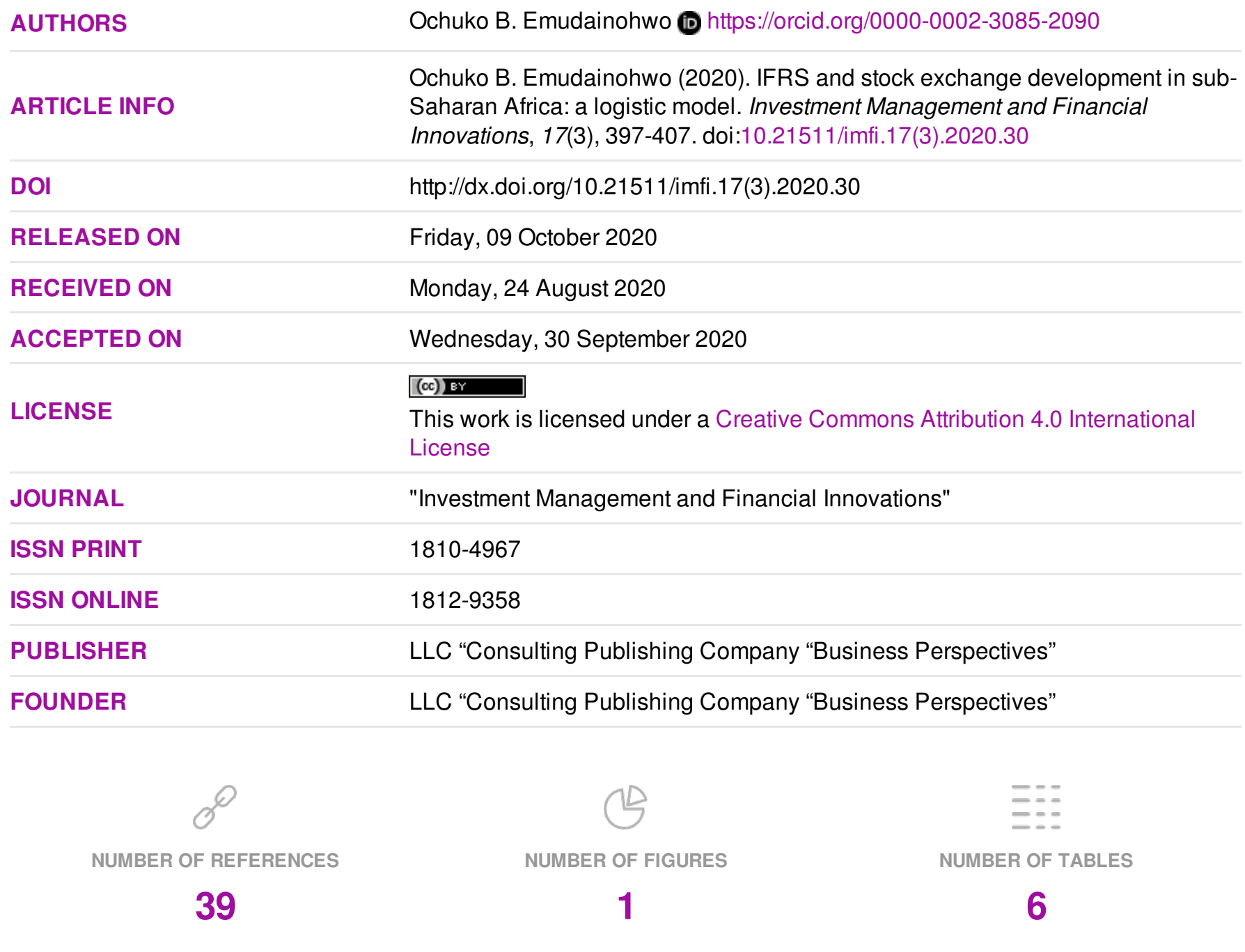

C The author(s) 2021. This publication is an open access article. 


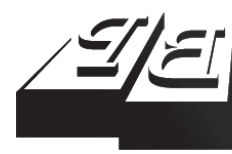

BUSINESS PERSPECTIVES

(O)

LLC "CPC "Business Perspectives" Hryhorii Skovoroda lane, 10, Sumy, 40022, Ukraine www.businessperspectives.org

Received on: $24^{\text {th }}$ of August 2020 Accepted on: $30^{\text {th }}$ of September 2020 Published on: $9^{\text {th }}$ of October, 2020

(๔) Dr Ochuko B. Emudainohwo, 2020

Dr Ochuko B. Emudainohwo, Lecturer/ Ph.D. Accountancy, UK, Delta State University, Abraka, Nigeria.

\section{IFRS AND STOCK EXCHANGE DEVELOPMENT IN SUB-SAHARAN AFRICA: A LOGISTIC MODEL}

\begin{abstract}
This study examines the impact of International Financial Reporting Standards (IFRS) on the stock exchange development (SED) in sub-Saharan Africa (SSA). The essence is to offer suggestions on how the adoption of IFRS in the SSA region can benefit their SED. The study employed logistic regression analysis of data for 40 SSA countries for the period 2010-2018. Data were extracted from the World Bank's World Development Index (WDI) database, sampled countries' stock exchange websites, and the IFRS website. The dependent variable (SED) took two values: 1 - if a stock exchange is established in the observed country's period, otherwise -0 . The model result was well fitted: $\mathrm{p}<0.0001$, correctly classified an overall SED accuracy up to $84.84 \%$ and excellent area predictive power at a receiver operator characteristic of 0.9347 . The study observed that IFRS had high degree of co-movement with SED, and changes in IFRS had a strong positive impact on SED. Besides, changes in market size, ICT infrastructure, and public sector management and institution (PSMI) had a positive and significant impact on SED. The odd ratio of SED compared to non-SED is greatest with IFRS (40.67 times), and for the other variables, the ratios are: market size (4.02), ICT infrastructure (1.26), and PSMI (2.73), respectively. On a greater extent, SSA countries should allow the use of IFRS for financial reporting to expedite SED.
\end{abstract}

\section{Keywords}

developing economies, SSA countries, logistic model, financial statement, accounting information, listed firms

JEL Classification

G15, M41, N27

\section{INTRODUCTION}

The stock exchange market provides great opportunities for mobilizing funds, better efficiency and resource allocation (Azeez \& Obalade, 2019). Shares of publicly held companies are issued and traded here either over the counter markets or through exchanges (the terms 'capital market', 'stock market', and 'stock exchange' are used interchangeably in this study). It plays a developmental role in the global economy and is a barometer of the level of business activities in an economy. Stock exchange provides avenue for investors' confidence through a strong regulatory framework, transparent disclosure and accountability by listed firms. In so doing, it improves the amount of firm's specific information capitalized into stock pricing through enhanced financial reporting standards. This improvement further enhances the reliability of the information contained in the financial reports for making investment decisions. The importance of the reliability of the information in financial statements is outlined in the Statement of Financial Accounting Concepts No. 2 (FASB, 2008); that is, the relevancy and reliability of information characteristics that make the accounting information useful.

Firms listed on stock exchanges are mandated to submit their financial statements to the stock exchange. And it serves as a means by which the listed firms interact and communicate their financial information to stock exchange stakeholders. Countries that intend to allow the use 
of IFRS, but have not started developing stock market, are increasingly doing so. This is because IFRS is becoming a global standard for preparing financial statements by a public company. This means that the adoption of IFRS is essential for the development of the stock exchange (P. V. C. Okoye, J. F. N. Okoye, \& Ezejiofor, 2014). Relatively, adopting or permitting the use of IFRS is expected to reduce information asymmetry, information risk, increase the speed at which information can be processed.

IFRS is expected to produce financial statements that are comparable in the face of increasing globalization of businesses. It is hoped that when firms globally adopt IFRS, investors' confidence worldwide will be increased. Since, it is expected to bring transparency, accountability and efficiency to financial markets around the world, which is a major motive for the standard, and to make auditing and regulation easier (Wiley Interpretation and Application of IFRS Standards, 2019). Currently, IFRS is either adopted, permitted and/or required by several countries for the presentation of their financial reports, particularly where their firms are listed on their domestic stock exchange markets. That is, some countries allow using IFRS even though they have not started SED. And it is still not permitted and/or not required for presenting financial statements in several other countries across the globe.

Motivated by the apparent relationship between the use of IFRS for reporting firms' performances and SED, relevant research has been conducted in both developing (Okoye et al., 2014) and developed economies (Hong \& Stein, 2007; Hayfa, Nadia, \& Elleuch, 2013). Most of the studies show that implementing IFRS is a driver of the trade volume movement in the stock markets of the European economies (Hong \& Stein, 2007; Hayfa et al., 2013).

Apart from the Johannesburg Stock Exchange that was established in 1887, most stock exchanges in the SSA region are relatively new. They are also the smallest and the least developed according to international standards, when measured by listing and capitalization. Currently, many SSA countries lag in sophisticated firms' regulatory systems, as such; adopting IFRS is expected to have a positive influence on the stock exchange market in the region. However, institutional and economic differences globally, and inherent regional factors either enhance or impede the benefits and costs accruing to the adoption of IFRS (Kimeli, 2017). Thus, the impact of IFRS on SSA SED needs to be studied in light of their underdevelopment. The determinants of SED are important to stock exchange stakeholders as well as policy makers seeking to improve their economy.

\section{LITERATURE REVIEW}

Given that other regional factors can impede or enhance SED, other than IFRS, the study includes other determinants of SED mentioned in the reviewed literature: market size, ICTI and PSMI. Production capacity, trade openness and transport services are used as control variables in the study.

\subsection{International financial reporting standards}

IFRS are more or less the rule of financial reporting for a global capital market. There are many arguments for the IFRS, which include factors such as: reduced differences in diverse accounting standards that can allay information processing costs, and increased cross-border investments and efficient capital allocation of scarce resources (Prochazka \& Pelak, 2015; Kimeli, 2017). Moving to IFRS can enhance the liquidity of capital markets and reduce companies' costs of capital by giving investors better information on firm performances. Adopting IFRS can help in a more informed valuation of equity markets, reducing the risk of adverse selection for the less-informed investors. Meanwhile, empirical studies on the determinants of SED confirm or question the correctness of theoretical models that relate IFRS to SED.

When examining the market reaction to earnings announcement, Ball and Brown (1968) showed that accounting information is a useful tool for investors in estimating security return risk and the expected market value. This suggests that ac- 
counting information reported using IFRS is a basis for evaluating stock markets, and this confirms findings that show IFRS influences stock price and, invariably, stock exchange market (Kim \& Shi, 2008; Wang \& Yu, 2008). Examining the effect of the national transparency on the performance of the Nigerian financial market, Ibrahim (2020) found a positive significant association between transparency and financial market performance. Though the findings of several studies indicated a positive bearing between IFRS and capital market, Prochazka and Pelak (2015), and Kimeli (2017) showed that the benefits were not been realized uniformly throughout the globe due to firms' and countries' inherent factors.

Given that the lack of institutional knowledge is combined with opaque financial reporting and obscure accounting rules, the adoption of IFRS that is acceptable to stock market participants means that IFRS will complement SED, and vice versa.

\subsection{Market size}

The market size required for a healthy SED should be relatively large so that it can absorb huge investments and investors can enjoy economy of scale benefits. Gross domestic product (GDP) is a good proxy for an economy's market size, and it has been documented empirically to affect stock market (Kuvshinov \& Zimmermann, 2020). GDP is a measure of the size of an economy's production of goods and services from the resources owned by the citizens of a particular area in a period of time (Stephany \& Krishnan, 2006). According to Kaldor (1961), SED is expected to evolve with market real activities. Though short-run deviations from the co-movement of SED and market real economic activities is expected, such as during the Covid-19 period. In the long run, the stock market will be coevolved with market real economic activities, such as with GDP (Kuvshinov \& Zimmermann, 2020).

The above assertion is supported by Kuvshinov and Zimmermann (2020), in their empirical examination of data for $1870-2015$ for 17 countries. The study shows that stock market size and GDP were closely related to each other until 1980s, but they diverged thereafter due to the induced sinking equity price and low discount rates. In this wise, GDP, as a proxy for market size, is expected to move in line with SED, unless it is distorted by some deep institutional factors.

Hsing (2014), in a study of Estonia, found that stock market index had a positive impact on GDP. Using the ARDL bound testing to examine the short-run and long-run relationships between macroeconomic determinants of the Nigerian stock market over the period 1981-2017, Azeez and Obalade (2019) showed that both short-run and long-run relationships exist between GDP and stock market development in Nigeria.

\subsection{ICT infrastructure}

Weak ICT infrastructure (ICTI) characterizes emerging economies (Mahajan \& Banga, 2005). The effects include limiting the free and fast flow of information to their potential users, as well as the lack of readily available data on the capital market (Okoye et al., 2014). Few African countries can boast of regularly producing and making timely, high-quality data available to the public (Kubota \& Zeufack, 2020), others even choose to keep them from the public as a confidential document (Jerven, 2013; Horn, Reinhart, \& Trebesch, 2019). The scarcity of automation for a robust electronic trading system, central depository and weak ICTI also hampers SED (Yartey \& Adjasi, 2007).

Given that the ICTI facility in the SSA region countries remains a hurdle for economic growth and productivity, it is likely to limit firm's listing in the region, since it is a main risk to business. Whereas ICTI is central to the determinants of international business activities (Dunning, 2006). A stock exchange with better ICTI facilities is expected to reduce costs and speed up its operation and activities (Yartey \& Adjasi, 2007). On the other hand, underdevelopment and low use of ICTI will induce high transaction costs and dissuade listing on the stock exchange (World Economic Forum, 2013-2014; Emudainohwo et al., 2018).

Pradhan (2015) examined the mutual association between ICTI, the depth of stock markets and economic growth of selected Asian countries over the period 1961-2012. The study found a long-run equilibrium association between the three variables, as well as the Granger causality relationship between ICTI and SED. In an examination of the 
ICTI impact on the growth of the Indian stock exchange, using a modified version of the Gompertz technology diffusion model, it was shown that ICTI contributes to the Indian capital market growth (Bhunia, 2011).

Lee, Alford, and Gardner (2017), while examining data from 81 countries over the period 1998-2014, show that the ICTI expansion has a positive effect on the stock market capitalization. They also show that the level of ICTI that may affect stock market capitalization varies substantially across countries. On the contrary, a study of the effects of ICTI on the Nigerian and Johannesburg stock exchanges shows that the internet use had a negative impact on their stock market indices except market capitalization (Okwu, 2015).

\subsection{Public sector management and institutions (PSMI)}

The PSMI cluster includes property rights and rule-based governance, the quality of budgetary and financial management, the efficiency of revenue mobilization, the quality of public administration, and transparency, accountability and corruption in the public sector (World Bank, 2020). SSA region lacks good governance, political stability and prudent government regulations, which hinder the normal development of the stock market. Transparency is a crucial element expected in PSMI. Most of institutions hide under the 'cover' of the democratic system of governance, but not transparency.

Earlier research found a strong association between transparency and corporate governance and the efficiency of the capital market (Lang \& Maffett, 2011; Ahmadi, 2015; Masry, 2015). With respect to PSMI, Afful and Asiedu (2014) found that business regulations, starting a business, closing it and enforcing contracts engender stock market activities in SSA. The implication of the finding is that in the SSA region, not all government institutions and business regulations stimulate SED. In their study of institutional quality effects on stock market performance, using panel data of 41 emerging countries for the period 1996-2011, Winful, Sarpong and Agyei-Ntiamoah (2016) found that the institutional quality has a positive significant impact on stock market per- formance. H. Khan, S. Khan, and Zuojun (2020) examined a panel set of 189 countries and showed that better institutions were important for financial development. Imran, Ejaz, Spulbar, Birau, and Nethravathi (2020), in a study of the association between stock market performance and country level governance indicators, found that stock market performance and governance indicators were positively related.

\section{AIMS}

Given that many countries of the SSA region lag behind in sophisticated firms' regulatory systems and there are institutional and macroeconomic differences between the region (a developing region) and other developed regions, coupled with the fact that globally the benefits and costs of implementing IFRS are far from been equal to companies and countries (Kimeli, 2017), this study aims to determine how IFRS will affect SED in the SSA region. The study's findings will contribute to answering the question of whether the adoption of IFRS will enhance or impede SED, in particular in SSA countries. Both macroeconomic and institutional factors are included as variables in this study. The results will be useful for policy makers and prospective investors as a guide when making investment decisions in the region.

\subsection{Hypotheses}

In the light of the review of SED, IFRS and other determinants of SED, the study puts forward the following hypotheses.

Theory emphasizes that stock exchange markets generate information to their stakeholders for potential investment and capital allocation. On the other hand, a lack of data transparency erodes credibility of a report, its opacity will fuel contagion and mask stock price in a stock market. The research problem is that the level of data disclosure and transparency in the SSA region is low (Kubota \& Zeufack, 2020), and it can reduce a competitiveness position. However, IFRS was adopted to address these weaknesses. Thus, the study hypothesizes that:

H1: IFRS is positively associated with SED. 
Given that SED is expected to evolve with market real economic activities, and that only relatively larger market size can secure a listing of a larger firm on the stock exchange, the study expects the same directional movement between market size and SED, and hypothesizes that:

\section{H2: Market size and SED have a significant posi- tive bearing.}

ICTIs are mainly a specialized technology, which is acquired and installed. They are easily adaptable. It is expected that their level of utilization will determine the extent of SED achievement, in particular that it will also affect the levels of free and fast information flows. The study hypothesizes that:

\section{H3: ICT infrastructure positively influences SED.}

Given that SED will be driven by good governance and strong institutions, the opposite will be the case of poor governance and weak institutions. Thus, the study hypothesizes that:

H4: There is a positive relationship between PSMI and SED.

\section{METHODOLOGY}

The study used data of 40 out of 48 SSA region countries for the period 2010-2018. The data were derived from the WDI database, sampled countries' stock exchange websites, and the IFRS website. The study's dependent variable is the status of SED in the SSA region (coded 1 if stock exchange is established in the country's observed year, otherwise 0$)$. The logistic transformation $\operatorname{logit}(\pi)$ was employed in this study. The form of multiple logistic regression model is expressed as follows:

$$
\begin{aligned}
& \operatorname{Logit}[\pi(x)]=\alpha+\beta_{1} x_{1}+ \\
& +\beta_{2} x_{2}+\beta_{3} x_{3}+\beta_{4} x_{4}+\ldots+\beta_{n} x_{n},
\end{aligned}
$$

where $x_{1}, x_{2}, x_{3}, \ldots, x_{n}$ are predictor variables, $\beta_{1}, \beta_{2}, \beta_{3}, \ldots, \beta_{n}$ are logit coefficients of the predictors, and $\alpha$ is constant. The logistic model shall be employed for logit, logit average marginal effects, and odd-ratio models. The study will as- sess whether the model fits the data well using the fitted dependent variable classification and ROC curve.

The model is specified as follows:

$$
\begin{aligned}
& S E D_{c, t}=\beta_{0}+\beta_{1} \text { IFRS }_{c, t}+ \\
& +\beta_{2} \text { MKTS }_{c, t}+\beta_{3} \text { ICTI }_{c, t}+ \\
& +\beta_{4} \text { PSMI }_{c, t}+\beta_{5} \text { PC }_{c, t}+ \\
& +\beta_{6} \text { OPEN }_{c, t}+\beta_{7} T_{c, t}+\mu_{c, t},
\end{aligned}
$$

where SED - Stock exchange development, IFRS - International Financial Reporting Standard, MKTS - market size proxy with GDP, ICTI - ICT infrastructure, PSMI - public sector management and institutions cluster index, $P C$ - production capacity, OPEN - trade open-

\begin{tabular}{|c|c|c|c|}
\hline Variable & $\begin{array}{l}\text { Proxy (for } \\
\text { the sampled } \\
\text { countries) } \\
\end{array}$ & Measurement & Source \\
\hline SED & Stock exchange & $\begin{array}{l}\text { If stock exchange is } \\
\text { established in year } t \\
=1 \text {, otherwise }=0\end{array}$ & $\begin{array}{l}\text { Sampled } \\
\text { country's } \\
\text { stock market } \\
\text { website }\end{array}$ \\
\hline IFRS & $\begin{array}{l}\text { Adoption and/ } \\
\text { or permitting } \\
\text { the use of IFRS }\end{array}$ & $\begin{array}{l}\text { If IFRS is adopted } \\
\text { and/or permitted in } \\
\text { year } t=1 \text {, otherwise } \\
=0\end{array}$ & IFRS (2020) \\
\hline Market size & $\begin{array}{l}\text { GDP (current } \\
\text { US\$) }\end{array}$ & Log of GDP & $\begin{array}{l}\text { World Bank } \\
(2020)\end{array}$ \\
\hline ICTI & $\begin{array}{l}\text { Fixed } \\
\text { telephone } \\
\text { subscriptions } \\
\text { (per } 100 \\
\text { people) }\end{array}$ & $\begin{array}{l}\text { Log of telephone } \\
\text { subscriptions (per } \\
100 \text { people) }\end{array}$ & $\begin{array}{l}\text { World Bank } \\
\text { (2020) }\end{array}$ \\
\hline PSMI & $\begin{array}{l}\text { Public sector } \\
\text { management } \\
\text { and Institutions } \\
\text { cluster index }\end{array}$ & $\begin{array}{l}\text { Public sector } \\
\text { management and } \\
\text { Institutions cluster } \\
\text { index }\end{array}$ & $\begin{array}{l}\text { World Bank } \\
(2020)\end{array}$ \\
\hline $\begin{array}{l}\text { Production } \\
\text { capacity }\end{array}$ & $\begin{array}{l}\text { Industrial } \\
\text { production } \\
\text { index }\end{array}$ & $\begin{array}{l}\text { Industrial } \\
\text { production index }\end{array}$ & $\begin{array}{l}\text { World Bank } \\
\text { (2020) }\end{array}$ \\
\hline $\begin{array}{l}\text { Trade } \\
\text { openness }\end{array}$ & $\begin{array}{l}\text { Trade } \\
\text { openness index }\end{array}$ & $\begin{array}{l}\text { (Import + export) of } \\
\text { goods and services } \\
\text { scaled by GDP }\end{array}$ & $\begin{array}{l}\text { World Bank } \\
(2020)\end{array}$ \\
\hline $\begin{array}{l}\text { Transport } \\
\text { service }\end{array}$ & $\begin{array}{l}\text { Transport } \\
\text { services (\% of } \\
\text { commercial } \\
\text { service } \\
\text { imports) }\end{array}$ & $\begin{array}{l}\text { Transport services } \\
\text { (\% of commercial } \\
\text { service imports) }\end{array}$ & $\begin{array}{l}\text { World Bank } \\
\text { (2020) }\end{array}$ \\
\hline
\end{tabular}
ness, $T S$ - transport services, $c=$ country $(1,2,3 \ldots$ $40), t$ - time $(1,2 \ldots, 9)$, and $\mu$ - errors term. The study variables are described in Table 1.

Table 1. Variable descriptions

Source: Researcher's computation (2020) 


\section{RESULTS}

Table 2 shows that 211 (58.61\%) years observation has SED, while 149 (41.39\%) years observation has no SED. The number of years observation shows that the use of IFRS for financial reporting is 193 (53.61\%), while 167 (46.39\%) have not used IFRS for financial reporting over the period 2010-2018. Table 3 shows that SED has a mean of 0.5861 , while IFRS has a mean of 0.5361 . It further indicates that years of country's SED is more than non-SED; and the use of IFRS is more than the non-use of IFRS. Their standard deviations (Table 3) of 0.4932 (SED) and 0.4994 (IFRS) are relatively the same, which suggests comparable volatility.

Correlation matrix (Table 4) shows that SED moves in line with IFRS (0.6246), market size proxy with GDP (0.4432), ICTI proxy with fixed broadband subscription (0.1752), PSMI (0.2504), and produc- tion capacity (0.1561). On the other hand, SED is inversely correlated with trade openness (-0.0515) and transport service $(-0.2487)$. Only IFRS (0.6246) and market size (0.4432) have moderately high correlation with SED. Other variables have a weak correlation with SED. Multicollinearity test (table omitted) shows that trade openness has a VIF of 1.55 (the highest), production capacity has a VIF of 1.05 (the lowest), and mean VIF is 1.27, which suggests no multicollinearity challenges.

The fit test (see Table 5) for the classification matrix of the logit model indicates that the fitted logit model correctly classifies SED with an overall accuracy of $84.84 \%$, and the rest $(15.16 \%)$ are misclassified. Further fit test, the ROC curve (Figure 1) shows that the area under ROC curve is 0.9347 , and this further suggests that the model is well fitted and it does have an excellent predictive power (Hilbe, 2009).

Table 2. SED description and the use of IFRS (2010-2018)

Source: Researcher's computation (2020).

\begin{tabular}{|c|c|c|c|c|c|}
\hline \multicolumn{3}{|c|}{ Number of years observation: SED } & \multicolumn{3}{|c|}{ Number of years observation: the use of IFRS } \\
\hline SED & Frequency & Percentage & IFRS used & Frequency & Percentage \\
\hline Yes (1) & 211 & 58.61 & Yes (1) & 193 & 53.61 \\
\hline No (0) & 149 & 41.39 & No $(0)$ & 167 & 46.39 \\
\hline Total & 360 & & & 360 & \\
\hline
\end{tabular}

Table 3. Variables statistic (2010-2018)

Source: Researcher's computation (2020).

\begin{tabular}{|c|c|c|c|c|}
\hline Variables & Mean & Std. Dev. & Min. & Max. \\
\hline SED & 0.5861 & 0.4932 & 0.0000 & 1.0000 \\
\hline IFRS & 0.5361 & 0.4994 & 0.0000 & 1.0000 \\
\hline Market size & 23.2270 & 1.4481 & 20.5596 & 27.0663 \\
\hline ICTI & 7.9449 & 3.6090 & 0.7821 & 18.4298 \\
\hline PSMI & 3.0068 & 0.4469 & 2.0000 & 4.1000 \\
\hline Production capacity & 0.1139 & 0.3181 & 0.0000 & 1.0000 \\
\hline Trade openness & 0.7593 & 0.3483 & 0.1910 & 2.1648 \\
\hline Transport service & 43.7521 & 16.8194 & 9.9359 & 81.4697 \\
\hline
\end{tabular}

Table 4. Correlation matrix

\begin{tabular}{|c|c|c|c|c|c|c|c|c|}
\hline No. & SED & IFRS & Market size & ICTI & PSMI & $\begin{array}{c}\text { Production } \\
\text { capacity }\end{array}$ & $\begin{array}{c}\text { Trade } \\
\text { openness }\end{array}$ & $\begin{array}{c}\text { Transport } \\
\text { service }\end{array}$ \\
\hline 1 & 1.0000 & & & & & & & \\
\hline 2 & 0.6246 & 1.0000 & & & & & & \\
\hline 3 & 0.4432 & 0.2376 & 1.0000 & & & & & \\
\hline 4 & 0.1752 & 0.0544 & 0.0166 & 1.0000 & & & & \\
\hline 5 & 0.2504 & 0.3468 & -0.0059 & 0.2030 & 1.0000 & & & \\
\hline 6 & 0.1561 & -0.1256 & 0.1414 & 0.0215 & -0.0181 & 1.0000 & & \\
\hline 7 & -0.0515 & -0.1368 & -0.2892 & 0.2297 & 0.1048 & -0.0210 & 1.0000 & \\
\hline 8 & -0.2487 & -0.1928 & 0.0230 & -0.1918 & -0.0909 & 0.0082 & -0.4637 & 1.0000 \\
\hline
\end{tabular}


Table 5. Stock exchange fit test classification

Source: Researcher's computation (2020).

\begin{tabular}{|c|c|c|c|}
\hline \multicolumn{4}{|c|}{ True } \\
\hline Classified & $D$ & $\sim D$ & Total \\
\hline+ & 119 & 22 & 141 \\
\hline- & 20 & 116 & 136 \\
\hline Total & 139 & 138 & 277 \\
\hline
\end{tabular}

\begin{tabular}{|c|c|c|}
\hline \multicolumn{3}{|c|}{ Classified + if predicted $\operatorname{Pr}(D)>=0.05$} \\
\hline \multicolumn{3}{|c|}{ True D defined as a Stock Exchange! = 0} \\
\hline Sensitivity & $\operatorname{Pr}(+\mid D)$ & $85.61 \%$ \\
\hline Specificity & $\operatorname{Pr}(-\mid \sim D)$ & $84.06 \%$ \\
\hline Positive predictive value & $\operatorname{Pr}(D \mid+)$ & $84.40 \%$ \\
\hline Negative predictive value & $\operatorname{Pr}(-D \mid-)$ & $85.29 \%$ \\
\hline False + rate for true $\sim D$ & $\operatorname{Pr}(+\mid \sim D)$ & $15.94 \%$ \\
\hline False - rate for true $D$ & $\operatorname{Pr}(-\mid D)$ & $14.39 \%$ \\
\hline False + rate for classified + & $\operatorname{Pr}(-D \mid+)$ & $15.60 \%$ \\
\hline False + rate for classified - & $\operatorname{Pr}(D \mid-)$ & $14.71 \%$ \\
\hline Correctly classified & & $84.84 \%$ \\
\hline
\end{tabular}

The regression results of the study are presented in Table 6. The models were well fitted as a whole ( $p$-value $<0.05)$. The result suggests that IFRS, market size, ICTI, PSMI, and production capacity are more likely to profit from SED. The model results (logit, logit average marginal effects, and odd-ratio models) are discussed concurrently as they relate to SSA countries examined in this study.

The results show that for every one-unit increase in the use of IFRS (in comparison to the non-use of IFRS), the opportunity ratio of SED will likely record an increase of 3.71 points at a significant threshold of $1 \%$. On average, this is associated with about a $37.2 \%$ increase in the probability of SED if other predictors are held constant, and it is about 40.67 times more likely to increase SED. The study found that improving market size by one unit, the log odds of SED are likely to increase by about 1.39 points at the $1 \%$ significance level. And where other independent variables are held constant, it is likely that SED will increase by $13.97 \%$ points and by 4.02 times over non-SED.

In the sample, where ICTI is improved by one unit, it is likely to increase the opportunity ratio of SED by 0.23 points at the $1 \%$ significance level. And it is associated with, on average, $2.36 \%$ points of SED if other independent variables are held constant. Furthermore, the result suggests that ICTI is also likely to progress SED by 1.26 times compared to the non-SED situation. Following the regression, for a one-unit increase in PSMI, the log odds of

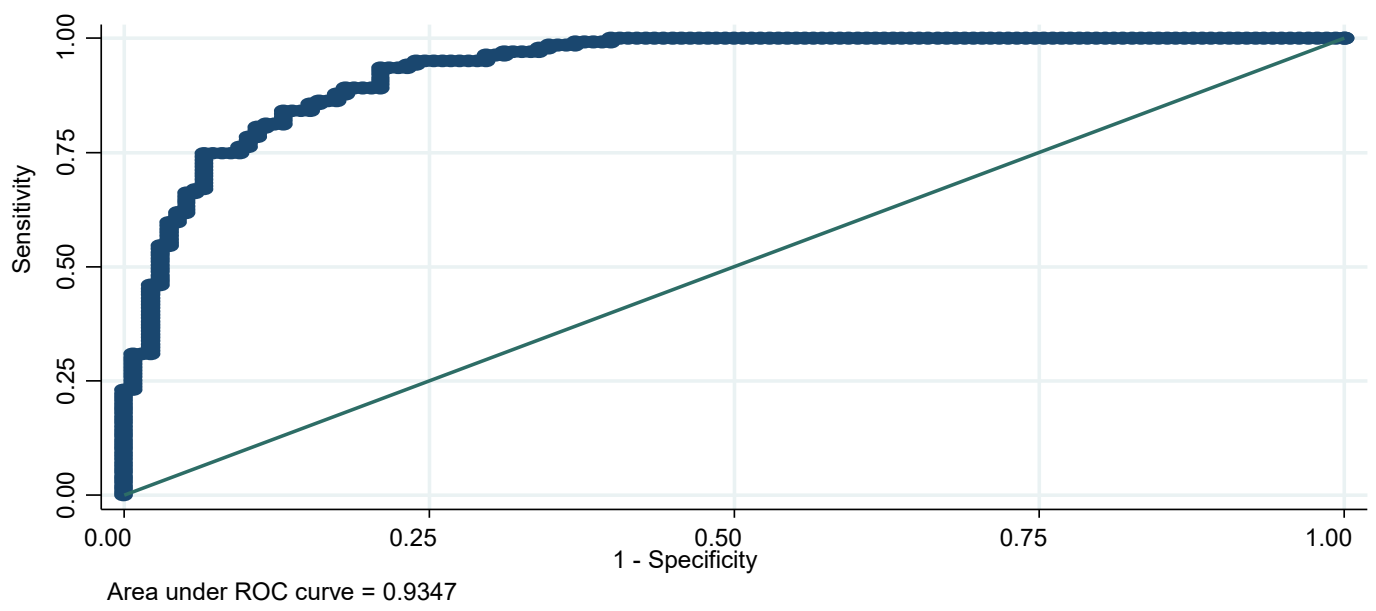

Figure 1. ROC curve 
Table 6. Regression results

Source: Researcher's computation (2020).

\begin{tabular}{|c|c|c|c|c|}
\hline SED & $t$ & Logit coefficients & $\begin{array}{l}\text { Logit average marginal } \\
\text { effect coefficients }\end{array}$ & Logistic model (odds ratio) \\
\hline IFRS & 7.48 & $3.7055^{* * *}$ & $0.3720 * * *$ & $40.6709 * * *$ \\
\hline Market Size & 5.57 & $1.3916^{* * *}$ & $0.1397^{* * *}$ & $4.0214^{* * *}$ \\
\hline ICTI & 3.23 & $0.2346^{* * *}$ & $0.0236 * * *$ & $1.2644^{* * *}$ \\
\hline PSMI & 2.02 & $1.0046^{* *}$ & $0.1008 * *$ & $2.7309^{* *}$ \\
\hline Production capacity & 3.01 & $2.3202 * * *$ & $0.2329 * * *$ & $10.1779 * * *$ \\
\hline Trade openness & 1.50 & 1.3535 & 0.1359 & 3.8709 \\
\hline Transport service & -1.67 & $-0.0237^{*}$ & $-0.0024 *$ & $0.9766^{*}$ \\
\hline cons & -5.35 & $-38.9100 * * *$ & & $1.26 \mathrm{e}^{17 * * *}$ \\
\hline Number of obs. & & 277 & 277 & 277 \\
\hline $\operatorname{LRChi}{ }^{2}(7)=$ & & 205.57 & & 205.57 \\
\hline Prob $>\mathrm{Chi}^{2}=$ & & 0.0000 & & 0.0000 \\
\hline Pseudo $R^{2}=$ & & 0.5353 & & 0.5353 \\
\hline
\end{tabular}

Note: $* *, * *$, and $*$ represent $\mathrm{p}$-levels of significance at $1 \%, 5 \%$ and $10 \%$, respectively.

SED are likely to increase by about one (1) point at the 5\% significance level. And holding other predictor variables constant, it is likely, on average, to cause about a $10.08 \%$ increase in SED. It is also likely to increase SED by 2.73 times compared to a situation with non-SED.

\section{DISCUSSION}

This study examines the impact of IFRS on SED in the SSA region. Of the studied country data for the years observed, country's years of SED and the use of IFRS are larger than non-SED and non-use of IFRS, respectively. IFRS and SED show a high degree of co-movement. This suggests that the SSA region countries, that is the developing stock exchange, are more likely to employ IFRS for financial reporting. IFRS has the greatest impact on SED. A positive significant association found between IFRS and SED supports the study hypothesis 1 , which states that IFRS and SED are positively associated. This is also corroborated by Kim and Shi (2008), Wang and Yu (2008) who show that IFRS influences stock prices and, as a result, the stock exchange market. The relationship is very strong and it suggests that using IFRS in the SSA region for financial reporting is expected to improve their SED. In turn, SED will attract firms to be listed on the SSA stock exchange markets.

The result supports hypothesis 2 , which states that market size and SED have a significant positive bearing. It also corroborated by Hsing (2014) who showed that the stock market index has a positive bearing on GDP (market size) in a study of the Estonian stock market. This result suggests that increasing the SSA region countries' market size is a condition for SED. ICTI had a positive and significant bearing on SED. The result supports hypothesis 3 and is corroborated by earlier studies that showed a positive relationship between ICTI and SED (Bhunia, 2011; Pradhan, 2015; Lee et al., 2017). It, however, fails to support the argument that the scarcity of soft infrastructure will hamper SED, which is in line with Yartey and Adjasi (2007) who found an inverse association between ICTI and SED. The result suggests that information could flow to potential users easily while its benefits may include reduced transaction costs in the stock exchange markets of the SSA region.

The result supports hypothesis 4 that expects a positive significant relationship between PSMI and SED. It also corroborated earlier studies that found a strong positive association between transparency and SED (Lang \& Maffett, 2011; Ahmadi, 2015; Masry, 2015; Winful et al., 2016; Imran et al., 2020). It, however, failed to support Afful and Asiedu (2014) who show that business regulations, starting a business, closing it and enforcing contracts engender stock market activities. Perhaps the result suggests that PSMI supports SED in the SSA region. Though transport services is another control variable in this study, it is worth mentioning that it has a weak negative association with SED. It probably supports the fact that transport services in the SSA region are poor. This suggests that an economic factor of production of goods and services in the SSA region impedes SED. 


\section{CONCLUSION}

Logistic regression was used to achieve the purpose of the study. The model was well fitted and it correctly classified SED with an overall accuracy of $84.84 \%$. The results are supported. The key finding of the study is that changes in IFRS have a strong and positive effect on SED. The number of times SED will change, in comparison with non-SED when there are changes in the explanatory variables, is greatest with IFRS (40.67 times). This shows that adopting IFRS by firms listed on the stock exchanges in the SSA region will enhance their SED. The other findings are: market size, ICTI, PSMI, and productive capacity are more likely to encourage SED, while, trade openness will mildly support SED. Transport services are unlikely to support SED. The numbers of times SED will change, in comparison to non-SED, are: market size -4.02$)$, ICTI - 1.26), and PSMI - 2.73 times, respectively.

The result is expected to assist policy makers and prospective investors as a guide when making investment decisions in the SSA region. Specifically, the study makes the following recommendations to enhance SED in the region:

a) institutional and infrastructural facilities should be strengthened to support market size and, of course, the stock market in the region;

b) ICTI in the capital market industry should be improved;

c) trade openness, although caution should be exercised;

d) production capabilities, especially outside the mineral resource sector, should be improved; and

e) transport service system should be improved to minimize its negative impact on SED.

Future researchers may explore the financial sector and decompose the non-financial sectors for study.

\section{AUTHOR CONTRIBUTIONS}

Conceptualization: Ochuko B. Emudainohwo.

Data curation: Ochuko B. Emudainohwo.

Formal analysis: Ochuko B. Emudainohwo.

Methodology: Ochuko B. Emudainohwo.

Resources: Ochuko B. Emudainohwo.

Validation: Ochuko B. Emudainohwo.

Writing - original draft: Ochuko B. Emudainohwo.

Writing - review \& editing: Ochuko B. Emudainohwo.

\section{REFERENCES}

1. Afful, K. B., \& Asiedu, K. F. (2014). Stock markets development in sub-Saharan Africa: business regulations, governance and fiscal policy. International Journal of Economics and Finance, 6(1), 15-31. Retrieved from https:// www.semanticscholar.org/paper/ Stock-Markets-Development-inSub-Saharan-Africa\%3A-AffulAsiedu/d36534c50f79c108f5c953a95c5e322c3b5841da

2. Ahmadi, F. (2015). The relationship between transparency and capital market efficiency in Iran exchange market. World Scientific News, 21, 111-123. Retrieved from http:// www.worldscientificnews.com/wpcontent/uploads/2015/07/WSN-212015-111-123.pdf

3. Azeez, B. A., \& Obalade, A. A. (2019). Macroeconomic determinants of stock market development in Nigeria: (19812017). Acta Universitatis Danubius, 15(1), 203-216. Retrieved from http://journals.univ-danubius.ro/ index.php/oeconomica/article/ view/5244
4. Ball, R., \& Brown, P. (1968). An empirical evaluation of accounting income numbers. Journal of Accounting Research, 6(2), 159-178. Retrieved from https://www.jstor.org/ stable $/ 2490232$ ? seq $=1$

5. Bhunia, A. (2011). An impact of ICT on the growth of capital market- empirical evidence from Indian stock market. Information and Knowledge Management, 1(2), 7-14. Retrieved from https://www. iiste.org/Journals/index.php/ IKM/article/view/745 
6. Dunning, J. H. (2006). Towards a new paradigm of development: Implications for the determinants of international business.

Transnational Corporations, 15(1), 173-227. Retrieved from http:// unctad.org/en/docs/iteiit20061a7_ en.pdf

7. Emudainohwo, O. B., Boateng, A., Brahma, S., \& Ngwu, F. (2018). Analysis of government policies, institutions and inward foreign direct investment: evidence from sub-Saharan Africa. Thunderbird International Business Review, 60(4), 523-534. https://doi. org/10.1002/tie.21942

8. FASB. (2008). Statement of Financial Accounting Concepts No. 2: Qualitative Characteristics of Accounting Information. Retrieved from https://www.fasb.org/jsp/ FASB/Page/PreCodSectionPage\&c $\mathrm{id}=1176156317989$

9. Hayfa, C., Nadia, T., \& Elleuch, S. (2013). The effect of IFRS on earnings quality in a European stock market: evidence from France. Interdisciplinary Journal of Research in Business, 2, 2046-714135. Retrieved from https://www.researchgate.net/ publication/300533833_The_Effect_of_IFRS_on_Earnings_Quality_in_a_European_Stock_Market_Evidence_from_France

10. Hilbe, J. M. (2009). Logistic regression models. Chapman \& Hall/CRC, Taylor \& Francis Group. Broken Sound Parkway NW.

11. Hong, H., \& Stein, J. (2007). Disagreement and the stock market. Journal of Economic Perspectives, 21(3), 109-28. Retrieved from https://www. aeaweb.org/articles?id=10.1257/ jep.21.2.109

12. Horn, S., Reinhart C., \& Trebesch, C. (2019). China's overseas lending (NBER Working Paper 26050). Retrieved from https://ideas.repec. org/p/nbr/nberwo/26050.html

13. Hsing, Y. (2014). Impacts of macroeconomic factors on the stock market in Estonia. Journal of Economics and Development Studies, 2(2), 23-31. Retrieved from http://jedsnet.com/vol-2-no2-june-2014-abstract-2-jeds

14. Ibrahim, A. (2020). National transparency and the performance of the financial market in Nigeria. international Journal of Business and Finance Management Review, 8, 10-14.

15. IFRS. (2020). Who uses IFRS standards? Retrieved from https:// www.ifrs.org/use-around-theworld/use-of-ifrs-standards-byjurisdiction/

16. Imran, Z. A., Ejaz, A., Spulbar, C., Birau, R., \& Nethravathi, P. S. R. (2020). Measuring the impact of governance quality on stock market performance in developed countries. Economic ResearchEkonomska Istraživanja, 33(1), 3406-3426. https://doi.org/10.1080 /1331677X.2020.1774789

17. Jerven, M. (2013) Briefing: for richer, for poorer: GDP revisions and Africa's statistical tragedy. African Affairs, 112(446), 138-147. https://doi.org/10.1093/afraf/ ads063

18. Kaldor, N. (1961). Capital accumulation and economic growth. In F. A. Lutz, \& D.C. Hague (Eds.), The theory of capital. St. Martins Press (pp. 177-222). Retrieved from http://gesd.free.fr/ kaldor61.pdf

19. Khan, H., Khan, S., \& Zuojun, F. (2020). Institutional quality and financial development: evidence from developing and emerging economies. Global Business Review. https://doi. org/10.1177/0972150919892366

20. Kim, J., \& Shi, H. (2008). Enhance disclosures via IFRS and stock price synchronicity around the world: Do analyst following and institutional infrastructure matter? (Working paper). The Hong Kong Polytechnic University. Retrieved from https://www.researchgate. net/publication/228258379_Enhanced_Disclosures_Via_IFRS and_Stock_Price_Synchronicity_Around_the_World_Do_Analyst_Following_and_Institutional_ Infrastructure_Matter

21. Kimeli, E. K. (2017). IFRS adoption and capital markets.
Journal of Finance and Accounting, 5(1), 19-30. Retrieved from https://www.researchgate.net/publication/327821505_IFRS_Adoption_and_Capital_Markets

22. Kubota, M., \& Zeufack, A. (2020). Assessing the returns on investment in data openness and transparency (World Bank Group Policy research working paper 9139). https://doi.org/10.1596/18139450-9139

23. Kuvshinov., \& Zimmermann, K. (2020). The big bang: stock market capitalization in the long run. European Historical Economics Society (EHES) (Working paper No. 135). Retrieved from https:// econpapers.repec.org/paper/heswpaper/0136.htm

24. Lang M., \& Maffett M. (2011) Economic effects of transparency in international equity markets: A review and suggestions for future research. Foundations and Trends ${ }^{\circ}$ in Accounting, 5(3), 175-241.

Retrieved from https://papers.ssrn. $\mathrm{com} /$ sol3/papers.cfm?abstract_ id $=1684195$

25. Lee, S. G., Alford, M. H., \& Gardner, L. (2017). The effects of information communication technology on stock market capitalization: A panel data analysis. Business and Economic Research, 7, 261-272. Retrieved from https://www.semanticscholar. org/paper/The-Effects-of-Information-Communication-Technology-Lee-Alford/a24fc99deee8c70c949fe3f1d691625881e6abdb

26. Mahajan, V., \& Banga, K. (2005). The 86 percent solution: How to succeed in the biggest market opportunity of the next 50 years. London: Financial Times Press. Retrieved from http:// ptgmedia.pearsoncmg.com/images/9780132485067/samplepages/0132485060.pdf

27. Masry, M. (2015). Measuring transparency and disclosure in the Egyptian stock market. Journal of Finance Bank Management, 3(1), 25-36. Retrieved from https:// www.researchgate.net/publication/283194689_Measuring_ Transparency_and_Disclosure_in_ the_Egyptian_Stock_Market 
28. Okoye, P. V. C., Okoye, J. F. N., \& Ezejiofor, R. A. (2014). Impact of the IFRS adoption on stock market movement in Nigerian corporate organization. International Journal of Academic Research in Business and Social Sciences, 4(9), 202-218. Retrieved from https:// ideas.repec.org/a/hur/ijarbs/ v4y2014i9p202-218.html

29. Okwu, A. T. (2015). ICT adoption and financial markets: A study of the leading stock exchange markets in Africa. Journal of Accounting and Management, 5(2), 53-76. Retrieved from https://hrcak.srce.hr/153500?lang=en

30. Osakwe, P. N. (2020). Building productive capacities and transforming economies to achieve sustained and inclusive development in Africa. Retrieved from https://www.un.org/development/desa/dspd/wp-content/ uploads/sites/22/2020/03/Osakwe_ DESAmeeting_Rome2020.pdf

31. Pradhan, R. (2015). Information communications technology (ICT) infrastructure impact on stock market-growth nexus: The panel VAR model. IEEE International Conference on Industrial Engineering and Engineering Management.
2015. 607-611. Retrieved from https://www.researchgate.net/ publication/282927872_Information_communications_technology_ICT_infrastructure_impact_on_stock_market-growth_ nexus_The_panel_VAR_model

32. Prochazka, D., \& Pelak, J. (2015). The development of capital market of new EU countries in the IFRS era. Procedia Economics and Finance, 25, 116-126. https://doi. org/10.1016/S2212-5671(15)007200

33. Stephany, G., \& Krishnan, S. (2006) GDP-indexed bonds: making it happen, UN Department of Economic and Social Affairs (DESA) Working Papers. Economic and Social Affairs, 21, 1-17. https:// doi.org/10.18356/3b5b07df-en

34. Wang, J., \& Yu, W. (2008). The information content of stock prices, reporting incentives and accounting standards: The international evidence (Working paper). The Hong Kong Polytechnic University. https://doi.org/10.1080/09638180.2 014.977802

35. Wiley Interpretation and Application of IFRS Standards. (2019). John Wiley and Sons, UK. Retrieved from https:// www.wiley.com/en-us/Wiley
+ Interpretation+and + Applic ation+of+IFRS+Standards-p9781119577300\#: :text=Wiley\%20 IFRS\%C2\%AE\%20Standards\%20 2019,Accounting\%20Standards\%20Board\%20(IASB).

36. Winful, E. C., Sarpong, D., \& Agyei-Ntiamoah, J. (2016). Relationship between institutional quality and stock market performance: evidence from emerging economies. African Journal of Business Management, 10(19), 469-484. https://doi. org/10.5897/AJBM2016.8153

37. World Bank. (2020). World Development Indicator. Retrieved from https://databank.worldbank. org/source/world-developmentindicators

38. World Economic Forum. (20132014). Global Competitiveness Index Data Platform. Retrieved from http://www3.weforum.org/ docs/WEF_GlobalCompetitivenessReport_2013-14.pdf

39. Yartey, C. A., \& Adjasi, C. K. (2007). Stock market development in sub-Saharan Africa: critical issues and challenges (IMF Working paper, WP/07/209, August, 2007). Retrieved from https://www.imf.org/external/ pubs/ft/wp/2007/wp07209.pdf 